\title{
Konsep al-Nabī al-Ummī dan Implikasinya pada Penulisan Rasm
}

\author{
Eva Nugraha
}

Fakultas Ushuluddin UIN Syarif Hidayatullah Jakarta

anugrahtuhan@yahoo.com

\begin{abstract}
The concept of al-nabī al-ummī has existed since the beginning of Islam. The Prophet Muhammad declared himself as al-nabī al-ummī, both in the Qur'an and Hadth. However, most Muslim scholars disagree if alummi means illiterate. Through the linguistic and historical approach, this paper would like to test the question "whether the implication of al-nabi alummì concepts in the Qur'anic orthography (rasm) is tawqîfī or iștilāḥī"
\end{abstract}

Keywords: Muhammad, al-ummī, rasm.

Abstrak: Konsep mengenai al-nabī al-ummī telah mapan sejak pertama kali kemunculan Islam. Nabi Muhammad sendiri memang mendeklarasikan dirinya sebagai al-nabī al-ummī, baik di dalam al-Qurān maupun Hadits. Para sarjana Muslim tidak setuju jika pengertian al-ummì hanya berarti buta huruf. Melalui pendekatan kebahasaan dan kesejarahan, tulisan ini akan menguji apakah implikasi konsep al-nabī al-ummì dalam penulisan mushaf al-Qur'ān merupakan tawqîī atau iștilāhịi

Kata Kunci: Muhammad, al-ummī, rasm. 


\section{Pendahuluan}

Kajian ini bukanlah seuatu yang baru, sebab sejumlah orang sudah membahasnya, seperti, Zwemer, ${ }^{1}$ Goldfeld, ${ }^{2}$ Athamina. ${ }^{3}$ Bagi kaum Muslim, penjelasan mengenai keummian Muhammad seringkali disandarkan pada keterjagaan al-Qur'ān dari pengaruh tulisan dan ideologi manusia. Sebagian lagi menjadikan keummīan sebagai bagian dari kemu ‘jizatan al-Qur’ān. Bagi sebagian peneliti Barat, term keummīan ini merupakan sesutu yang mustahil. Di antara mereka yang memandang bahwa Nabi Muhammad bisa menulis adalah Bell, Nöldeke-Schwally, Widergen. ${ }^{4}$ Mustahil bagi seorang yang berstatus nabi dengan pengaruh lingkungan Arab yang sudah terbiasa dengan budaya tulis, memiliki seorang pemimpin yang tidak bisa menulis.

Tulisan ini ingin menyatakan bahwa Nabi Muhammad adalah betul seorang nabi yang ummì. Penulis ingin mengaitkannya dengan pertanyaan keijtihadan ortografí (rasm) al-Qur'ān. Asumsi awal penulis adalah, bila Nabi Muhammad memiliki kemampuan untuk membaca dan menulis maka sudah bisa dipastikan bahwa rasm alQur'ān adalah tawqîfì, atau berdasarkan arahan dan petunjuk Nabi dari Tuhan. Namun apabila keummīan Muhammad dimaknai sebagai ketidakmampuan membaca, menulis dan menghitung, maka seharusnya pendukung konsep ini setuju bahwa rasm al-Qur'ān adalah ijtihad dari para sahabat. Maka sangat wajar bila penisbatan rasm al-Qur'ān tidak ke Nabi Muḥammad akan tetapi ke 'Utsmān ibn 'Affān.

Pelacakan sumber dari tulisan ini dilakukan melalui kitab-kitab tafsir, Hadits, dan buku kajian 'ulūm al-Qur'ān. Term ummī dan segala derivasinya dijadikan kata kunci untuk mencari keterhubungan istilah-istilah tersebut di dalam al-Qur'ān dan Hadits. Term ijtihādì dan tawqīfì digunakan untuk mencari tema-tema apa saja yang menjadi ketentuan Allah, Nabi-Nya serta usaha rasional sahabat dalam kodifîkasi al-Qur'ān masa 'Utsmān ibn 'Affān.

Untuk memaparkan kajian di atas, penulis membagi tulisan ini pada beberapa sub judul. Pertama, Arab pra-Islam: antara jāhilìyah dan ummiyah. Kedua, melacak pengetahuan Nabi yang ummì. Ketiga, peran Nabi dalam penyusunan mushaf (mushaf), dan terakhir, kesimpulan. 


\section{Arab pra-Islam di antara Jāhilīyah dan Ummīyah}

Islam tidaklah seperti agama Yahudi dan Nasrani di mana tempat kedua agama itu turun telah dikelilingi oleh budaya literasi. Sangat sulit untuk menemukan bukti-bukti tertulis untuk menunjukkan bahwa sudah ada budaya literasi di Arab pada masa awal Islam. Sekalipun ada, jumlahnya relatif sedikit, yaitu di daerah Arab Selatan. Kemungkinan upaya penulisan al-Qur'ān dipengaruhi oleh budaya Kristen dan Yahudi di daerah tersebut terutama dari Ethiopia. ${ }^{5}$ Apakah sedikitnya budaya literasi ini menyebabkan orang Arab praIslam disebut jāhilīyah atau sedikitnya budaya literasi merupakan akar dari istilah ummìyat al-'Arab?

Dari sekian jumlah makna, jähilīyah biasanya diasosiasikan dengan kebodohan, seakan-akan hal tersebut berlawanan dengan ketidakmilikan atas pengetahuan ( $\mathrm{i} l m$ ). Penelusuran sederhana yang dilakukan oleh penulis memerlihatkan bahwa dari 4 ayat yang mencantumkan kata jāhilìyah, tidak ada satu pun yang terkait dengan kebodohan yang dimaknai dengan ketidakmampuan menulis dan membaca, seperti termaktub dalam QS. al-Mā'idah/5: 50,6 Ālu 'Imrān/3: 154,7 al-Ah'zab/ 33: 33,8 al-Fath/48: 26.'

Berikut adalah pemaknaan lain yang bisa dicari dalam al-Qur'ān antara lain: 1) Perilaku bangsa Arab pra Islam yang memberikan sesembahan pada berhala QS. Al-Mä’idah/5: 103,10 memakan daging tersebut sesembahan berhala, menyembelih tidak atas nama Tuhan, memakan bangkai dan darah,11 2) Nama-nama yang disembah, contohnya bintang Syirā, 12 berhala: al-Lāt, al-'Uzza, dan al-Manāh,13 3) Perilaku bangsa Arab pra Islam yang mengharamkan istri yang telah dizihr dan menyamakan anak angkat sebagai anak kandung, ${ }^{14}$ Berperang hanya untuk kepentingan dunia, ${ }^{15}$ mewarisi janda ayah, ${ }^{16}$ mengharamkan yang halal, ${ }^{17}$ mengundi nasib dengan panah, ${ }^{18}$ melaksanakan riba $(r i b \bar{a}),{ }^{19} q \bar{i} s \bar{a} s,{ }^{20}$ membangga-banggakan leluhur, ${ }^{21}$ dan membunuh sebagian anak perempuan mereka.

Menurut Lane, dalam sumber Muslim awal kata jāhilīyah diartikan dalam dua macam. Pertama, ketidakhadiran pengetahuan yang seharusnya diketahui, sebagai terjemahan simple. Kedua, kepercayaan yang tidak sesuai dengan fakta atau realitas. Sekalipun demikian, kata jahl bermakna pula kebodohan, perilaku yang 
salah, memercayai sesuatu yang berbeda dari yang sebenarnya, dan melakukan sesuatu perilaku yang berbeda dari yang seharusnya. ${ }^{22}$ Yang disebutkan di atas lebih cenderung memaknai jahl sebagai lawan dari 'ilm (keberpengetahuan). Dalam al-Qur'ān disebutkan, saat Nabi Nūh meminta doa untuk keselamatan keluarganya, "Hai Nūh', sesungguhnya dia bukanlah termasuk keluargamu (yang dijanjikan akan diselamatkan), sesungguhnya (perbuatan)nya perbuatan yang tidak baik. Sebab itu janganlah kamu memohon kepada-Ku sesuatu yang kamu tidak mengetahui (hakekat)nya (mā laysa laka bihì 'ilm). Sesungguhnya Aku memeringatkan kepadamu supaya kamu jangan termasuk orangorang yang tidak berpengetahuan (min al-jähilin)." 23

Kata jāhil di atas berbanding terbalik dengan kata 'älim (orang yang memiliki pengetahuan). Ibn Manzūr, menyatakan bahwa kata jil pada ayat ini merupakan ketidaktahuan atas ayat Allah. ${ }^{24}$ Sekalipun demikian, maknanya tidak berubah, bahwa jähil adalah ketidaktahuan. Hanya saja objek dari ketidak tahuannya adalah ayat Allah.

Adapun jāhilīyah, berdasarkan pelacakan atas beberapa kamus atau ensiklopedia dalam tradisi Islam, dimaknai sebagai zamān alfatrah atau masa sebelum datangnya Islam. ${ }^{25}$ Seringkali disebut sebagai jaman kegelapan, dan Islam menjadi penerang orang Arab kala itu sehingga mereka masuk ke jaman penuh cahaya Tuhan. Kegelapan karena apa yang mereka lakukan tidak sesuai dengan apa yang ada pada Islam. Jika perbuatan atau perilaku yang dikerjakan telah mengalami proses Islamisasi, perbuatan dan perilaku tersebut tidak lagi menjadi perilaku jahilizyah akan tetapi sudah masuk ke dalam syari'at Islam. Sebagai contoh, ḩad ataupun qīșās, tetap diberlakukan hanya saja Islam lebih memilih memberikan maaf lebih mulia dari itu semua.

Goldziher telah membahas secara panjang mengenai istilah jähilīyah. Ia berkesimpulan bahwa jāhilīyah merupakan antonim dari ḩilm atau kesopanan. Term jāhilīyah ia artikan nyaris sebanding dengan barbarian bukan kebodohan ataupun ketidaktahuan. ${ }^{26}$ Rosenthal, menganggap bahwa kesimpulan Goldziher meragukan, karena konsep barbarian tidak bisa ditemukan pada Muhammad sebelum kenabian. ${ }^{27}$ Kesimpulan penulis atas istilah jähilìyah, lebih 
condong pada kondisi bangsa Arab yang belum menjalankan ajaran sesuai dengan syari'at Islam.

Bahasan selanjutnya, beralih pada pertanyaan: "Apakah jāhilīyah semakna dengan ummiyah?” Secara bahasa, istilah ini selalu dirujuk ke akar katanya yaitu a-m-m. Namun ia lebih sering dikaitkan dengan kata ummī. Ibn Manzūr mengutip beberapa pendapat untuk menjelaskan hal ini. 1) al-Zujjāj, mengaitkan kata ummì dengan kondisi umat yang belum pernah memelajari al-Kitāb, sebagaimana tersirat dalam al-Qur'ān, "Dan di antara mereka ada yang ummīyūn, yang tidak mengetahui al-Kitāb, kecuali dongengan bohong belaka dan mereka hanya menduga-duga." ${ }^{28}$ 2) Abū Ișh>q menisbahkan kata ummī pada kondisi intrinsik seorang ibu yang tidak menulis, karena menulis bagi orang Arab bukanlah merupakan pekerjaan seorang perempuan, melainkan pekerjaan laki-laki. Juga ia dinisbahkan pada bayi yang dilahirkan oleh seorang ibu, di mana bayi tersebut tidak memliki kemampuan untuk menulis. ${ }^{29}$

Dalam Tafsìr Aḅkām disebutkan bahwa makna ummī pada alA'rāf: 157-158 adalah dinisbahkan kepada al-ummah al-ummìyah, atau umat yang sedari awal tidak mengetahui apapun sebagaimana saat bayi baru lahir. Mereka belum memelajari cara membaca dan menulis. Riwayat Ibn 'Umar menegaskan bahwa ummah ummīyah adalah kondisi ketidakmampuan membaca dan menulis. Kesimpulan ini merupakan argumen atas QS. al-'Ankabūt: 48, "Dan kamu tidak pernah membaca sebelumnya (al-Qur'ān) sesuatu Kitab pun dan kamu tidak menulis suatu Kitab dengan tangan kananmu; andaikata demikian, benar-benar ragulah orang yang mengingkari(mu)." ${ }^{30} \mathrm{Ibn}$ 'Abbās, menambahkan bahwa kata ummī bermakna pula tidak bisa menghitung. ${ }^{31}$ Mungkin ini penjelasan tambahan dari Ibn 'Abbās agar sesuai dengan Hadits di bawah ini.

Dalam sejumlah kitab Hadits disebutkan bahwa ummīyah adalah sifat bangsa Arab yang tidak menulis dan berhitung "Innā ummah ummīyah, lā naktub wa-lā nahsub, al-syahr hākadzā, hākadzā, wahākadzā." 32 Hadits-Hadits ini ditempatkan pada bab puasa, saat menjelaskan jumlah hari dalam sebulan. Nabi memberi isyarat dengan kedua jari tangannya sampai tiga kali ( $h \bar{a} k a d z \bar{a})$. Sekalipun tidak begitu jelas dalam teksnya, namun kemungkinan isyarat jari 
tangan ini dilakukan sebanyak enam kali. Tiga kali pertama dengan menunjukkan 10 jari tiga kali untuk menyatakan bahwa jumlah hari dalam satu bulan sebanyak 30. Tapi dalam tiga kali kedua, Nabi mengakhirinya dengan melipat satu jari jempolnya, sehingga jumlahnya adalah ${ }^{29}$.

Sebetulnya Hadits-Hadits yang menerangkan jumlah hari dalam sebulan cukup banyak, akan tetapi tidak semuanya diawali dengan penjelasan ummīyah. ${ }^{33}$ Bagi penulis, adanya penjelasan ummīyah dengan kata là naḩsub (tidak bisa berhitung), terkesan agak ganjil. Bagaimana mungkin seseorang atau para sahabat saat itu bisa tahu bahwa jumlah (10 i 10 i 10 atau 9) adalah 30 atau 29. Kemampuan mereka untuk mengatakan bahwa jumlahnya 29 atau 30 adalah kemampuan berhitung. Memang tidak bisa dipungkiri bahwa berhitung dalam bentuk ilmu berhitung (matematika), saat itu belum berkembang di Arab. ${ }^{34}$ Orang Arab mulai mengenal dan menransfer ilmu matematika dari Yunani ke dalam Bahasa Arab sekitar abad 8 dan 9. ${ }^{35}$ Sebagai contoh, Abū Ja'far Muhammad ibn Mūsā al-Khawārīzmī (780-850 M), adalah seorang Muslim yang mengembangkan matematika Aljabar pada Abad ke 9. ${ }^{36}$

Berdagang merupakan salah satu pekerjaan orang Arab pra-Islam. Bahkan pada akhir Abad ke 6 para pedagang besar dari Makkah telah mendapat kekuasaan monopoli atas kegiatan perdagangan yang melewati pantai tepi Barat Arabia ke Mediterania. Mereka berdagang dari ujung Selatan, Yaman hingga Damaskus di Syiria pada musim-musim tertentu. Hal ini sebagaimana yang direkam dalam QS. al-Quraysy/106:2.37 Seorang pedagang, tentunya, harus mahir menghitung. Bagaimana dia bisa mengetahui jumlah keuntungan atau kerugiannya bila tidak dapat berhitung, terlebih kebanyakan dari pedagang Arab adalah pedagang besar. Selain dari itu, term-term yang digunakan al-Qur'ān banyak pula mengadopsi istilah pedagangan seperti: mizann, hisb, tijrah. Secara tidak langsung menunjukkan bahwa perhitungan merupakan bagian dari doktrin yang harus dipahami dan diajarkan dalam Islam. ${ }^{38}$

Al-Zarqānī menyepakati apa yang diuraikan oleh al-Alūsī bahwa kondisi ummīyah dalam Hadits di atas bukanlah sesuatu yang tetap dan selamanya orang Arab tidak bisa menulis dan berhitung, akan 
tetapi hanya sementara. Bilamana kondisi ketidakmampuan menulis dan membaca ini benar, bagaimana mengambil manfaat atas suruhan untuk membaca dan menulis atas Nabi yang tidak bisa membaca dan menulis. Dengan demikian dipastikan Nabi memiliki kemampuan untuk membaca dan menulis. ${ }^{39}$

Penjelasan lainnya bisa dilihat dari suruhan Nabi pada tawanan perang Badar mengajarkan tulisan pada bangsa Arab. Sekalipun tidak seluruhnya mampu untuk membaca dan menulis, orang Arab yang mampu membaca dan menulis berkembang semakin banyak. Oleh sebab itu, term ummīyah yang ditafsirkan sebagai ketidakmampuan untuk menulis juga berhitung harus dikaji ulang.

\section{Melacak Pengetahuan Nabi yang Ummī}

Subbab ini ingin mengetengahkan pembicaraan mengenai bagaimana Nabi, sebagai seorang yang ummī mendapatkan pengetahuan. Apakah ia mendapatkannya dari membaca tulisan, ataukah dengan cara lainnya? Sebelum melakukan menjawab pertanyaan tersebut, penulis akan mengulas kembali istilah ummi yang terkait langsung dengan Nabi, baik dalam tafsir maupun Hadits.

Konsep al-nabi al-ummī, tidak hanya sebuah konsep yang ada secara idealitas, dalam artian bahwa seorang Muhammad harus ummī agar al-Qur'ān muncul sebagai kitab yang mengandung mu'jizat, akan tetapi kalimat tersebut pun masuk ke dalam ranah fīqh. Kata salawat dalam salat dalam beberapa riwayat meniscayakan adanya tambahan kata al-Nabi al-ummī pada ujung kalimat Muhammad, ${ }^{40}$ ataupun tentang perintah untuk membaca salawat secara umum. ${ }^{41}$ Nabi pun menyatakan dirinya sebagai al-nabi al-ummì sampai tiga kali. Dalam satu riwayat yang agak panjang, beliau menjelaskan tentang posisi dirinya sebagai orang yang diberikan wahyu yang harus didengar dan ditaati serta perintah mengikuti kitābullah bila dirinya telah wafat. ${ }^{42}$ Hadits ini diriwayatkan oleh Ahmad hanya dianggap munfarid. ${ }^{43}$

Kata al-Nabì al-ummì muncul dua kali dalam al-Qur'ān secara berurutan dalam dua ayat 157 dan 158 dari surat al-A'rāf. Ayat 157 menyebutkan, "Orang-orang yang mengikut Rasul, Nabi yang ummi yang (namanya) mereka dapati tertulis di dalam Taurat (Tawrāt) dan Injil (Injīl), yang menyuruh mereka mengerjakan yang ma'rūf dan 
melarang mereka dari mengerjakan yang mungkar..." Secara literal ayat ini menjelaskan tentang informasi kenabian Muhammad telah tertulis dalam kitab Tawrāt dan Injīl. Adapun ayat berikutnya berupa ajakan agar kaum Yahudi dan Nasrani untuk mengimani kenabian Muhammad, “...Berimanlah kamu kepada Allah dan Rasul-Nya, Nabi yang ummī yang beriman kepada Allah dan kepada kalimat-kalimatNya (kitab-kitab-Nya) dan ikutilah dia, supaya kamu mendapat petunjuk." Dari dua ayat di atas, memang tidak dapat ditemukan penjelasan langsung apa yang dimaksud dengan al-ummī sebagai salah satu sifat dari Nabi Muhammad. Oleh sebab itu para mufassir merujuknya ke dalam arti kebahasaan; juga pada Hadīts Nabi salah satunya, hadīts ummah ummīyah, seperti yang telah diuraikan di atas.

Cara lain untuk menjelaskan term ini ialah dengan mencari term sejenis di dalam al-Qur'ān. Kalimat ummìyūn, ummìyin, dan umm dirujuk sebagai penjelas dari istilah ummī yang menyifati Nabi.

1. ummìyūn: "Dan di antara mereka ada ummìyūn, yang tidak mengetahui al-Kitāb, kecuali dongengan bohong belaka dan mereka hanya menduga-duga". ${ }^{4}$ "Kemudian jika mereka mendebat kamu (tentang kebenaran Islam), maka katakanlah: 'Aku menyerahkan diriku kepada Allah dan (demikian pula) orang-orang yang mengikutiku'. Dan katakanlah kepada orangorang yang telah diberi al-Kitäb dan kepada ummìyūn: 'Apakah kamu (mau) masuk Islam..." 45

2. ummìyin: "Di antara ahli Kitab ada orang yang jika kamu memercayakan kepadanya harta yang banyak, dikembalikannya kepadamu; dan di antara mereka ada orang yang jika kamu memercayakan kepadanya satu dinar, tidak dikembalikannya kepadamu kecuali jika kamu selalu menagihnya. Yang demikian itu lantaran mereka mengatakan: "Tidak ada dosa bagi kami atas ummìin, mereka berkata dusta terhadap Allah, padahal mereka Mengetahui. ${ }^{46}$ "Dia-lah yang mengutus kepada ummìyin seorang rasul di antara mereka, yang membacakan ayat-ayat-Nya kepada mereka, menyucikan mereka dan mengajarkan mereka Kitāb dan hikmah. dan sesungguhnya mereka sebelumnya benar-benar dalam kesesatan yang nyata." 47

3. umm: "Dan ini (al-Qur'ān) adalah kitab yang telah Kami turunkan 
yang diberkahi; membenarkan kitab-kitab yang (diturunkan) sebelumnya dan agar kamu memberi peringatan kepada (penduduk) Umm al-Qurā (Makkah) dan orang-orang yang di luar lingkungannya...” QS. al-Anām/6: 92. "Demikianlah Kami wahyukan kepadamu al-Qur’ān dalam bahasa Arab, supaya kamu memberi peringatan kepada Umm ul-Qurā (penduduk Makkah) dan penduduk (negeri-negeri) sekelilingnya ..." QS. al-Syūrā/42: 7.

Dari 3 kalimat di atas, para mufassir terbagi ke dalam 3 kelompok dalam menafsirkan ayat al-Nabi al-ummī, yaitu:

1. Nabi yang diutus pada kaum yang tidak memiliki kitab suci. Mereka berargumen berdasarkan term ummīyūn pada QS. alBaqarah/2 : 78. Fakhr al-Dīn al-Rāzī adalah mufassir yang condong pada kesimpulan ini. ${ }^{48}$

2. Nabi yang diutus untuk orang Makkah dan sekitarnya. Dasar dari kesimpulan ini adalah term umm pada QS. al-An'ām/6: 92 dan al-Syūrā/42: 7, serta term ummīyin pada (QS. al-Jumu'ah/62: 2). Mereka yang berkesimpulan seperti ini antara lain: al-Qurțubi ${ }^{49}$ dan Ibn Katsīir ${ }^{50}$

3. Nabi yang tidak memiliki/sedikit kemampuan dalam menulis dan membaca. Kesimpulan ini sebagaimana yang telah dijelaskan pada bagian ummiyah. Mereka yang condong untuk menakwilkan seperti ini di antaranya adalah: al-Tabarī, ${ }^{51}$ Ibn Hātim, ${ }^{52}$ dan alBaghāwī. ${ }^{53}$

Dengan merujuk pada ayat-ayat di atas, para sarjana Barat berbeda pandangan mengenai makna ummī. Berikut adalah beberapa pendapat yang penulis rujuk dari M. Denny, mereka antara lain: Nöldeke dan Schwally memaknainya sebagai laikos yang setara dengan àlmāya dalam bahasa Aramaik. ${ }^{54}$ Horovitz, tidak setuju dengan interpretasi atas ayat-ayat di atas disamakan karena termterm tersebut berbeda. Ummīyūn pada QS. 2:78 sebagai pembeda antara Israel dari ummot hä-oläm. ${ }^{55}$ Wensinck, menyatakan bahwa ada relasi yang sangat erat antara term ummah dan ummī. Ummah, secara bahasa berarti people (masyarakat), dan menjadi komunitas dalam perspektif keagamaan. Dari kacamata profan, ummah semakna dengan ethnos dan ummī adalah ethnikos. Jika dihubungkan dengan 
Nabi Muhammad, maka dia adalah "gentiles" (bukan orang Yahudi) yang diutus untuk ummīyūn. ${ }^{56}$ Apa yang menjadi perhatian utama sarjana Barat memang terkesan banyak merekam istilah-istilah Yahudi. Hal ini bisa jadi tidak bisa dielakkan karena pada ayat-ayat di atas terhubung dengan kaum Yahudi. Selain misalnya, karena pengetahuan mereka tentang Yahudi memberi latar yang cukup kuat atas kesimpulan-kesimpulan yang diambil.

Sekalipun demikian, bila dibandingkan dengan hasil penelusuran pada tafsir-tafsir, sebagaimana yang penulis ungkap di atas, ragam pendapat mereka tidak jauh berbeda. Hanya pemberian istilahnya saja yang lain. Untuk menutup ragam pendapat di atas, penulis mengutip kata-kata Watt: "There is no argument here for Muhammad being completely unlettered, but at most for his being ignorant of the Jewish and Christian scriptures." 57 Penulis sepakat dengan kalimat ini. Sekalipun doktrin yang beredar lebih cenderung berpihak pada ketidakmampuan Nabi Muhammad dalam menulis dan membaca, tidak ada satu ayat pun yang cukup tegas mengatakan bahwa Nabi tidak mampu menulis dan membaca. Hanya rujukan HaditsHadits yang memerlihatkan asumsi bahwa Nabi tidak bisa menulis, membaca, bahkan berhitung.

Apakah Nabi benar-benar tidak bisa membaca? Ayat berikut sering menjadi dasar bahwa Nabi tidak pernah membaca dan menulis sama sekali. Bunyi QS. al-'Ankabūt/29: 48, “Dan kamu tidak pernah membaca $(t a t l \bar{u})$ sebelumnya sesuatu kitab pun dan kamu tidak (pernah) menulis (takhuttu) suatu kitab dengan tangan kananmu; andaikata (kamu pernah membaca dan menulis), benar-benar ragulah orang yang mengingkari(mu)," bila ditelisik lebih dalam, ada sesuatu yang perlu diperhatikan dalam ayat di atas. Pertama, kalimat tidak membaca suatu kitab sebelum al-Qur'ān, memiliki kemungkinan bahwa Nabi bisa membaca sesuatu setelah al-Qur'ān ini turun dan ditulis. Kedua, kalimat wa lā takhutțu (dan tidak menuliskannya), menggunakan kata khatt, dalam makna menulis dengan bagus. Maka secara tersirat ada kemungkinan bahwa Nabi pernah menulis (yaktub), dengan tulisan yang kurang bagus, dalam bahasa al-Ṭabarī lā yuhsin al-kitābah. ${ }^{58}$ Bagi al-Alūsī, kemungkinan Nabi mampu membaca dan menulis setelah al-Qur'ān turun, terkait dengan manfaat apa yang bisa 
diambil bisa kondisi Nabi sebaliknya. ${ }^{59}$ Al-Alūsī pun memunculkan pertanyaan, apakah Nabi pernah menulis barangkali sesaat. Ada riwayat yang menyebutkan bahwa Nabi pernah menulis pada saat penulisan perjanjian Hudaybiyah. Akan tetapi riwayat lainnya menegaskan bahwa Nabi tidak pernah menulis. Riwayat mengenai penulisan di situ adalah suatu majāz. ${ }^{60}$

Dari sejumlah kata Hadits yang menyiratkan Nabi pernah membaca ada pada riwayat saat Nabi melakukan Isrä'-Mi' rāj: "Ra'aytu 'alā bāb al-jannah maktūban: al-qard bi-tsamāniyyah 'asyr, wa-alsadaqah bi-al-'asyr. Faqultu yā Jibrīl mā bālu al-qard a'zam ajran? Qàla: li'anna al-qard lā yatīka illā wa-huwa muhtāj wa-rubbamā waqa'at al-ṣadaqah fì ghanī."61 Al-Albānī menyatakan bahwa sanad Hadits ini $d a$ 'îf. Namun ada yang perlu diperhatikan pada Hadits di atas. Di dalamnya memang tidak ada kalimat yang merujuk pada kata qara'a ataupun talā sebagai ujaran yang bermakna membaca. Matn-nya menggunakan kata ráaytu (saya melihat) tertulis di pintu surga bahwa pahala sadaqah 10 kali lipat, dan pahala menghutang 18 kali lipat. Bagaimana seorang yang tidak tahu tulisan bisa membaca sesuatu dan menghitung bahwa 18 lebih besar dari 10, bilamana al-ummī dimaknai tidak bisa membaca dan menghitung. Di antara sekian jumlah riwayat mengenai al-nabi al-ummī, riwayat dari 'Awn ibn 'Abdullāh adalah satu yang bisa disimpulkan bahwa Nabi memiliki kemampuan membaca dan menulis sebelum dia wafat. ${ }^{62}$

Kalaulah Nabi diasumsikan memiliki kemampuan untuk membaca, menulis, dan menghitung, kemudian dari mana ia mendapatkan pengetahuan/keterampilan tersebut? Merujuk pada alQur'ān, bisa dipastikan bahwa "Allahlah yang memberi pengetahuan Nabi atas apa yang dia tidak ketahui sebelumnya, sebagaimana Ia menurunkan al-kitāb dan hikmah." 63 Dan dia akan terus mencari pengetahuan, karena dia memahami bahwa "orang yang diberi ilmu pengetahuan dan orang beriman akan ditinggikan beberapa derajat." ${ }^{64}$ Kehausan akan ilmu tidak hanya terlihat pada HaditsHadits yang menyuruh untuk mencari ilmu tapi juga pada doa yang ada di al-Qur'ān? "Rabbì zidnī ilman." ${ }^{65}$ Kecuali itu, pengetahuan Nabi tentang hal yang 'gaib' hanya ia dapatkan sedikit, dan Allahlah yang mengetahuinya. ${ }^{66}$ Sarjana Barat memang memertanyakan 
pengetahuan Nabi Muhammad tentang kaum Yahudi, Nasrani serta isi kitab suci terdahulu. Akan tetapi selain itu, seperti prinsipprinsip embriologi, astronomi, dan geologi, bisa dikatakan sulit untuk disanggah. Bagaimana orang yang hidup 15 abad yang lalu mengetahui prinsip-prinsip keilmuan tersebut? ${ }^{27}$

Bagi non-Muslim, pengetahuan Nabi Muhammad mengenai apa yang ada di dalam Injil merupakan sesuatu yang terus berkembang saat dia berdakwah. Hal tersebut bisa terjadi karena dia menerima informasi dari beberapa orang. ${ }^{68}$ Bisa jadi yang disebut orang yang memberi informasi tentang orang Kristen, kaum Yahudi, dan orang-orang Samaria adalah Waraqah ibn Nawfal, sepupu dari Khadijah. Rudolf Macuch, memberikan argumentasinya dengan merujuk salah satu riwayat dari ibn Hisyām: "Wa kāna Waraqah qad tanașsara, wa-qara’a al-kutub wa-sami'a min ahl al-Tawrät wa-al-Injïl." Sebagai contoh yang diajukannya adalah arah kiblat waktu salat. Nabi Muhammad menjiplak arah salat yang dilakukan oleh kaum Yahudi pada saat itu, di mana mereka berkiblat ke Jerusalem. Hurgronje berasumsi bahwa ini merupakan cara Nabi Muhammad untuk meluluhkan hati orang Yahudi agar mengikuti ajarannya. Namun pada akhirnya hal tersebut harus diakhiri karena Islam harus melakukan pembedaan dari agama sebelumnya, dan diarahkanlah qiblat saat salat ke maqām Ibrāhìm. ${ }^{70}$

Asumsi-asumsi di atas bisa jadi memiliki kebenaran. Hanya saja, apakah Waraqah menceritakan semua hal mengenai kitab suci umat terdahulu, persis sama dengan apa yang ada di Tawrat ataupun Injil? Quraish Shihab menjelaskan bahwa terdapat banyak perbedaan mengenai kisah-kisah nabi yang ada di dalam al-Qur'ān dan Perjanjian Lama. ${ }^{71}$ Begitu juga dengan pengalihan kiblat ke Ka'bah setelah Jerusalem bukan berawal untuk membujuk kaum Yahudi agar mereka merasa menjadi bagian dari komunitas.

\section{Peran Nabi dalam Penyusunan Mushaf}

Kaum Muslim menyepakati bahwa al-Qur'ān adalah kalāmullāh yang diturunkan kepada Nabi Muhammad secara mutawatir, menjadi pedoman hidup dan keagamaan. Dalam proses menyejarahnya kalām tersebut akhirnya ditulis, sebagian berdasarkan turunnya wahyu. Kemudian ia disusun berdasarkan urutan bacaan Nabi dan disatukan 
di antara dua cover (bayna lawhayn/bayna daf atayn). Bagaimana satu kaum ('Arab) yang sedari awal diberi label ummah ummīyah yang tidak bisa menulis, berhitung, dan membaca mampu menranskrip fīrman Allah ke dalam orthografī Arab. Kesimpulan al-Zarqanī di atas menjadi jawabannya. Bahwa ketidakmampuan menulis dan membaca pada bangsa Arab bukanlah statis, melainkan dinamis dan mencapai puncaknya saat muncul kaligrafī yang indah. Agar terlihat runtut, di bawah ini disajikan proses awal tersusun mushaf.

Secara umum, kaum Muslim sepakat bahwa al-Qur'ān sudah tertulis semua sebelum Nabi Muhammad wafat. ${ }^{72}$ Hanya saja tulisantulisan tersebut masih terpisah dalam bentuk materi yang berbedabeda. Ada di pelepah kurma, tulang, batu tipis, dan lain-lain. Di antara sekian jumlah sahabat yang hafal dan mengerti tentang alQur'ān, hanya Zayd yang dipilih oleh Abū Bakr dan 'Umar untuk melakukan pengumpulan teks-teks yang berserak. Pada awalnya Zayd menolak permintaan tersebut, dengan alasan bahwa hal itu belum pernah diperintahkan oleh Nabi. Bila pun ia mau, Zayd paham bahwa pengumpulan al-Qur'ān bukanlah sesuatu yang mudah. Ia menggambarkan bahwa lebih baik memindahkan gunung daripada harus mengumpulkan teks-teks yang berserak. Namun pada akhirnya Zayd menerima tugas tersebut. ${ }^{73}$

Riwayat lain menunjukkan bahwa 'Alī ibn Abī Talib adalah orang yang pertama dalam pengumpulan teks-teks al-Qur'ān yang berserak. Pada riwayat ini, 'Alī sampai berjanji untuk tidak melepaskan sorbannya, dan tetap berada di rumah Rasul, sampai selesai pengumpulan mushaf. Hal itulah yang menjadi salah satu penyebab yang dinyatakan 'Alī ketika ia tidak hadir saat kaum Muslim membaiat Abū Bakr.

Belum pernah ada data yang pasti berapa lama Zayd mengumpulkan teks-teks yang berserak sehingga menjadi satu kesatuan. Bisa jadi masih dilanjutkan pada masa 'Umar ibn Khat,t,b. Beberapa sarjana Barat memandang bahwa kumpulan al-Qur'ān telah dilakukan oleh Zayd menjadi dokumen kekhalifahan, karena ia akhirnya disimpan oleh 'Umar kemudian diberikan ke Hafșah. Dokumen tersebut baru diteima oleh khalifah berikutnya, 'Utsmān ibn 'Affān. Saat 'Utsmān memeritahkan Zayd untuk menyatukan 
ragam mushaf menjadi satu ragam. ${ }^{74}$

Pada masa 'Utsmān, telah banyak sahabat yang menyebar keluar Madinnah, di antara mereka ada yang memiliki mushaf dan mengajarkannya pada penduduk. Mushaf-mushaf mereka satu dengan yang lain ada perbedaan, sehingga saat terjadi pertemuan antara para murid yang membaca teks mushaf dengan ragam berbeda terjadilah perselisihan di antara para murid tersebut. Ada riwayat pula yang menunjukkan bahwa hal ini terjadi pula di Madinnah. Upaya Zayd pada saat ini bisa jadi lebih mudah karena telah ada dokumen awal yang dipinjam dari Hafșah. Akan tetapi proses penulisan ulang ini tidak bisa dianggap mulus. Tim harus menyusun urutan surat, menuliskannya dalam bahasa Quraysh, menduplikasi 4-6 mushaf lainnya dengan orthografī yang sekarang dibakukan menjadi rasm 'Utsmānī.

Mushaf ${ }^{75}$ yang dibuat pertama kali disebut sebagai mushaf alimām (mushaf standar), sarjana Muslim seringkali menyebutkan dengan Mushaf'Utsmānì, atau Mașāhif'Utsmānīyah. 'Utsmān dianggap sebagai penggagas yang berjasa sehingga namanya menjadi predikat dari mushaf al-Qur'ān. Kūfī merupakan $\operatorname{tulisan}^{76}$ dari mushaf ini, dan bisa dipastikan ditulis dengan tulisan huruf konsonantal, tanpa harakat, bahkan tanpa penanda jenis huruf, sekalipun penanda huruf sebenarnya sudah dikenal sejak awal masa Islam atau akhir masa pra Islam. ${ }^{77}$

Dari penjelasan di atas muncul pertanyaan, apakah susunan teks al-Qur'ān ada pada mushaf sesuai sebagaimana keinginan Nabi? Tentunya untuk menjawab hal ini cukup sulit karena tidak ada (belum ditemukan) data sejarah yang berupa manuskrip teks al-Qur'ān pada awal Islam yang selamat hingga kini. Namun demikian masalah ini sudah menjadi pembahasan sarjana Muslim awal, dengan tema apa saja yang tawqīfì dan ijtihādì dalam penyusunan mushaf.

Penyusunan ayat dalam satu surat merupakan tawqīfí, atas petunjuk Nabi. Al-Suyūtī mengumpulkan sejumlah riwayat mengenai hal ini, salah satunya riwayat dari al-Makkī dan lainnya, ia berkata: "Tartīb al-Āyāt fì al-suwar bi amr min al-Nabi wa lammā lam ya’mur bi dzālik fì awwal al-baräah turikat bi lä basmalah" ${ }^{78}$ Riwayat lain yang selalu menjadi rujukan adalah perkataan Nabi mengenai penempatan 
satu ayat di antara ayat lainnya "da' 'àyah kadzā fì mawdi ‘ $i k a d z \vec{a}$ " ${ }^{79}$

2. Para ulama berbeda pandangan mengenai susunan surat dalam al-Qur'ān, antara tawqîfì dan ijtihādì. Ibn Hajar menyatakan, "Susunan sebagian surat atas surat lainnya, atau sebagian besarnya tidak menegasikan bahwa penyusunan tersebut merupakan tawqîfi. ${ }^{80}$ Namun kondisi susunan surat yang ada pada mushafmushaf sahabat menunjukkan lain. Mereka memiliki susunan surat yang agak berbeda dari susunan Mushaf 'Utsmānī." 11

3. Sarjana Muslim berbeda pendapat mengenai ketawqīian rasm mushaf. $^{82}$

a) Pendapat pertama menyatakan bahwa rasm mushaf tawqīfì. Penulisan mushaf tidak diperkenankan kecuali memakai rasm 'Utsmānī. Mereka menyandarkan argumennya pada beberapa riwayat. Pertama, riwayat dari Mu'āwiyah, saat dia sedang menulis di hadapan Nabi yang bersabda: "Alqī al-dawāh, wa harrif al-qalam, wa-aqim al-bä, wa-farriq al-sin, wa-là tu'awwir al-mìm, wa-hassin Allah, wa-mudd al-Rahmān, wa-jawwid al-Rahìm." ${ }^{3}$ Dalam al-Jāmi karya al-Baghdādī, ada riwayat Anas yang mengesankan bahwa Nabi telah melakukan telaah tulisan, dengan mengatakan, "Idzā kataba ahadukum (bismillāh al-rahmōnn al-rahīm), falyamudd al-raḥmān." ${ }^{44}$ Al-Suyūtī mencantumkan riwayat di atas sebagai atsar yang diterima Ibn alAsyittah dari 'Umar ibn 'Abd al-'Azīz. ${ }^{85}$ Oleh sebab itu, hanya ada satu riwayat sebagai alasan yang relatif bisa menyatakan bahwa Nabi mengetahui bahkan melakukan cross-check ulang tulisan para sahabat. Bagi al-Zarqān̄̄ ${ }^{86}$ dan Isma' ${ }^{\text {i }}{ }^{87}$, pandangan yang menganggap rasm merupakan hasil petunjuk Nabi dianut oleh jumbūr.

b) Pendapat kedua adalah pendapat yang menyatakan bahwa rasm bukanlah sesuatu yang tawqïfi dari Nabi Muhammad, melainkan sebuah istilah/term yang disetujui oleh 'Utsmān. Sekalipun demikian, para ulama menyepakati untuk tidak menyalahi pola penulisan al-Qur'ān yang dilakukan pada masa 'Utsmān. Abū 'Amr al-Dānī, mengutip perkataan al-Imām Mālik, saat ditanya mengenai kebolehan untuk menyalahi huruf wa dan alif dalam mushaf, ia berkata "tidak." 88 Pada riwayat lainnya disebutkan: “... 
Mālik ditanya: Apa pendapatmu mengenai orang yang diminta untuk menulis mushaf saat ini. Apakah ia menuliskannya sebagaimana huruf hijāìyah yang beredar sekarang. Ia menjawab: saya tidak memiliki pendapat tentang itu. Akan tetapi dia harus menuliskannya sebagaimana tulisan yang awal". ${ }^{89}$ Atas alasan ini pula, mengapa syarat untuk qiräah yang diterima tidak boleh menyalahi Rasm 'Utsmānì. Mereka didukung oleh madzhabmadzhab fīqh, baik Hanafī, Mālikī, Hanbalī maupun Syāfī'ì. AlQațtn menganggap bahwa pendapat inilah yang paling rājih̆.90 Al-Zarqānī dan Ismāîil memasukkan pendapat kedua ini pada kelompok pertama, karena pendapat kedua bagi keduanya adalah rasm yang iștilāḩi, sebagaimana dijelaskan di bawah ini. ${ }^{91}$

c) Pendapat ketiga, kelompok yang menyatakan bahwa rasm mushaf bukan tawqīfì melainkan iștiläḥi. Mereka membolehkan menulis mushaf selain dengan rasm 'Utsmānī. Bagi mereka, tidak ada dasar hukum yang sangat pasti, baik dalam al-Qur'ān ataupun Sunnah bahwa penulisan al-Qur'ān harus memakai rasm tertentu. Nabi tidak pernah menyuruh sahabatnya untuk menggunakan suatu rasm dalam penulisan teks al-Qur'ān. ${ }^{92}$ Ibn Khaldūn, Ibn Taymīyah dan al-Qāḍi Abk Bakr merupakan sebagian dari pendukung pendapat ini. ${ }^{93}$ Bagi al-Zarqānī, pendapat ketiga adalah pendapat yang tidak hanya menyebut bahwa rasm adalah iștilāhì, akan tetapi menjadi kewajiban untuk menyalahi rasm muṣhaf al-imm. Ia merujuk pada perkataan al-Azīz 'Abd al-Salām: "Wa lā tajūz kitābatuh lahum bi-al-rasm al-'Utsmānī al-awwal, li'allā yūqi' fì tafsìr min al-juhhāl..." akan tetapi pada saat yang sama, harus menjaga apa yang telah dilakukan oleh salaf al-șälị atas al-rasm al-'Utsmānī. ${ }^{94}$

Bila ditelisik lebih dalam uraian di atas, penulis berkesimpulan bahwa Nabi memiliki peranan yang cukup besar dalam pola penyusunan ayat dalam setiap surat. Namun berbeda peranannya saat surat-surat yang telah tersusun disusun ulang untuk dituliskan ke dalam mushaf. Peran sahabat lebih banyak dari Nabi, sekalipun apa yang mereka lakukan bersumber dari riwayat-riwayat yang diterima. Penelusuran akan sangat sulit, saat melacak dari mana istilah tawqī $\overline{\text { ì }}$ pada proses penulisan mushaf, ataupun pada saat 
penulisan teks al-Qur'ān di hadapan Nabi. Istilah tersebut bisa jadi baru muncul pada abad keduapuluh, seperti di dalam buku: alZarqānī (w. 1367/1948),95 Subḥi al-Sāliḥ, ${ }^{96}$ Mannā' al-Qațtānn, ${ }^{97}$ Isma'îl. ${ }^{98}$ Penelusuran istilah (rasm-tawqîfî) terhadap kitāb ilmu alQur'ān abad pertengahan seperti al-Itqān karya al-Suyūṭī (w. 911 H.) dan al-Burhān karya al-Zarkasyī (w. 794 H.), tidak menemukan hasil yang baik kecuali satu riwayat tentang khat dari Ibn Fāris. Ia mengatakan bahwa "khat adalah tawqīfī." ${ }^{99} \mathrm{Hal}$ ini tidak menjelaskan bahwa rasm 'Utsmānī tawqīfî. Al-Suyūțī mencantumkannya pada bab 76 mengenai khat yang tertulis dan adab menuliskannya.

Selanjutnya tulisan ini menjawab "apakah Nabi mengetahui tulisan teks al-Qur'ān?,” atau dengan kata lain ia memiliki kemampuan untuk membaca teks. Berlandaskan riwayat dari Mu'āwiyah di atas ialah kemungkinan Nabi mengetahui tulisan pada teks al-Qur'ān. Namun belum ditemukan riwayat lain yang lebih rinci daripada itu. Contoh, apakah ada riwayat di mana Nabi memberi petunjuk agar kata Ibrāhim pada surat al-Baqarah ${ }^{100}$ harus ditulis tanpa alif dan $y \bar{a}$, dan dibedakan dari kata tersebut pada surat yang lain. ${ }^{101}$ Atau adakah penjelasan yang berasal dari Nabi bahwa huruf muqatta'ah tidak ditulis sebagaimana bunyi bacaannya akan tetapi hanya ditulis huruf-hurufnya. Pada masalah ini, al-Suyūṭī hanya memberi alasan iktifä bi-syuhratihā." 102

\section{Simpulan}

Dari uraian di atas, penulis akhirnya menyimpulkan bahwa ada ketidaklurusan pola logis dari jumhur mengenai konsep alnabi al-ummī bila dihadapkan pada tawqīfìyah penulisan rasm mushaf. Pilihan makna ummī sebagai predikat ketidakmampuan membaca dan menulis, merupakan tafsiran yang paling masyhur. Jikalau mereka yang berpendapat seperti ini berpikir lurus dalam menghukumi penggunaan rasm 'Utsmānì, maka hukumnya adalah ijtihādī. Dari, data yang diurai di atas, terjadi kebalikannya: mereka menghukumi rasm al-awwal sebagai tawqīfì, wajib dilaksanakan, dan haram menyalahinya. Wa Allah a'lam. 


\section{Catatan Akhir}

1 Ia termasuk orang yang memertanyakan apakah Nabi Muhammad bisa menulis dan membaca. Dia menyandarkan asumsinya pada penelitian yang telah dilakukan oleh Wellhausen, Wustenfeid, Cheikho, Lammens, Huart. Mereka menyatakan bahwa riwayat yang menyatakan ilmu membaca tidak diketahui pada bangsa Arab kecuali setelah diintrodusir oleh Harb (ayah dari Abk Sufyn) memiliki tingkat ketidakakuratan. Bagi mereka, kemungkinan orang Arab sudah memahami tulisan karena kontak perdagangan antara Makkah dengan Yaman telah terjadi sejak lama. Samuel Marinus Zwemer, "The 'Illiterate' Prophet" dalam The Muslim World, 11: 344-363.doi: 10.1111/j.1478-1913.1921. tb01870.x padahttp://onlinelibrary.wiley.com/doi/10.1111/j.1478-1913.1921. tb01870.x/abstract. Lih. Samuel Marinus Zwemer, Studies in Popular Islam: a collection of papers dealing with the superstitions and beliefs of the common people (The Sheldon Press, 1939), 100-120.

2 Isaiah Goldfeld, "The Illiterate Prophet (Nabī Ummī): An Inquiry into the Development of a Dogma in Islamic Tradition," dalam Der Islam 57 (1980): 58-67. Kutipan diambil dari Walid A Saleh, "The Arabian Context of Muhammad's Life" dalam Jonathan E Brockopp (ed.), The Cambridge Companion to Muhammad (Cambridge: Cambridge University Press, 2010), 33.

3 Khalil Athamina, "An-Nabiyy al-Ummiyy': An Inquiry into the Meaning of a Qur'ānic Verse,” dalam Der Islam 69 (1992): 61-80. Kutipan diambil dari Daniel A. Madigan, "Mary and Muhammad: Bearers of the Word" dalam The Australasian Catholic Record 80:4 (Oct., 2003), 417-427.

${ }^{4}$ Geo Widengren, Muhammad, the Apostle of God, and His Ascension. King and Saviour, no. 5 (Uppsala: Uppsala University Arsskrift, 1950), 150 ; Theodore Noldeke and Fredick Schwally, Geschichte des Qorans (Zweite Auflage: berbeite von Friedrich Schwally: 1909-1938), vol. 1, 14 ; Richard Bell (penj.), The Qur'an: Translated with a Critical Rearrangement of the QS. (Edinburgh: T. \& T Clark, 1937-1939). Kutipan diambil dari Daniel A. Madigan, The Qur'än's selfimage: writing and authority in Islam's scripture (Princeton: Princeton University Press, 2001), 14-19.

5 Peter Stain, "Literacy in Pre-Islamic Arabia: an Analysis of the Epigraphic Evidence”, dalam Angelika Newright et.all (eds.), The Qur'ann in Context : Historical and Literary Investigations into the Qurânic Milieu (Leiden: Brill, 2010), 255.

6 "Dan hendaklah kamu memutuskan perkara di antara mereka menurut apa yang diturunkan Allah, dan janganlah kamu mengikuti hawa nafsu mereka. Dan berhati-hatilah kamu terhadap mereka, supaya mereka tidak memalingkan kamu dari sebahagian apa yang telah diturunkan Allah kepadamu. Jika mereka berpaling (dari hukum yang telah diturunkan Allah), maka ketahuilah bahwa sesungguhnya Allah menghendaki akan menimpakan musibah kepada mereka disebabkan sebahagian dosa-dosa mereka. Dan sesungguhnya kebanyakan manusia adalah orang-orang yang fasik. Apakah hukum Jahiliyah yang mereka 
kehendaki, dan (hukum) siapakah yang lebih baik daripada (hukum) Allah bagi orang-orang yang yakin?” QS. 5: 49-50.

7 Kemudian setelah kamu berdukacita, Allah menurunkan kepada kamu keamanan (berupa) kantuk yang meliputi segolongan dari kamu, sedang segolongan lagi telah dicemaskan oleh diri mereka sendiri, mereka menyangka yang tidak benar terhadap Allah seperti sangkaan Jähilìyah.

8 "Dan hendaklah kamu tetap di rumahmu dan janganlah kamu berhias dan bertingkah laku seperti orang-orang Jähilizyah yang dahulu dan dirikanlah salat, tunaikanlah zakat dan taatilah Allah dan Rasul-Nya. Sesungguhnya Allah bermaksud hendak menghilangkan dosa dari kamu, hai Ahl al-Bayt dan membersihkan kamu sebersih-bersihnya."

9 Ketika orang-orang kafír menanamkan dalam hati mereka kesombongan (yaitu) kesombongan Jähilìyah lalu Allah menurunkan ketenangan kepada RasulNya, dan kepada orang-orang mu'min dan Allah mewajibkan kepada mereka kalimat-taqwa dan adalah mereka berhak dengan kalimat taqwa itu dan patut memilikinya. Dan adalah Allah Maha Mengetahui segala sesuatu.

10 "Allah sekali-kali tidak pernah mensyari'atkan adanya bahirah, säibah, wașilah dan häm. Akan tetapi orang-orang kafîr membuat-buat kedustaan terhadap Allah, dan kebanyakan mereka tidak mengerti." Bahirah: ialah unta betina yang telah beranak lima kali dan anak kelima itu jantan, lalu unta betina itu dibelah telinganya, dilepaskan, tidak boleh ditunggangi lagi dan tidak boleh diambil air susunya. Säibah: ialah unta betina yang dibiarkan pergi ke mana saja lantaran sesuatu nadzar. Seperti, jika seorang Arab Jāhilīyah akan melakukan sesuatu atau perjalanan yang berat, maka ia biasa bernadzar akan menjadikan untanya sāiibah bila maksud atau perjalanannya berhasil dengan selamat. Wașilah: seekor domba betina melahirkan anak kembar yang terdiri dari jantan dan betina, maka yang jantan ini disebut wașilah, tidak disembelih dan diserahkan kepada berhala. Hām: unta jantan yang tidak boleh diganggu gugat lagi, karena telah dapat membuntingkan unta betina sepuluh kali. Perlakuan terhadap bahīrah, sāibah, waṣilah dan hm ini adalah kepercayaan Arab Jāhilīyah. Pada ayat lain disebutkan bahwa kebiasaan Jāhilīyah adalah memotong telinga binatang yang akan dikorbankan untuk berhala (QS. al-Nisā"/4: 119).

11 "Diharamkan bagimu (memakan) bangkai, darah, daging babi, (daging hewan) yang disembelih atas nama selain Allah, yang tercekik, yang terpukul, yang jatuh, yang ditanduk, dan diterkam binatang buas, kecuali yang sempat kamu menyembelihnya, dan (diharamkan bagimu) yang disembelih untuk berhala. Dan (diharamkan juga) mengundi nasib dengan anak panah, (mengundi nasib dengan anak panah itu) adalah kefasikan" QS. al-Māidah/5: 3 .

${ }^{12}$ QS. al-Najm/53: 49, "Dan bahwasanya Dialah yang Tuhan (yang memiliki) bintang syi ' rä".

${ }^{13}$ QS. al-Najm/53: 19-20, "Maka apakah patut kamu (hai orang-orang musyrik) menganggap al-Lāt, al-'Uzza dan Manāh yang ketiga, yang paling terkemudian (sebagai anak perempuan Allah)” (QS. al-Nisā”/4: 117.)

${ }^{14}$ QS. al-Ahzāb/33: 3-4, al-Mujādilah/58: 1. 
${ }^{5}$ QS. al-Anfāl/8: 65.

${ }^{16}$ QS. al-Nisā/4: 19. Lih. penjelasan al-Ṭabarī dalam Ibn Jarīr al-Ṭabarī, Tafsìr al-Tabari,

${ }^{17}$ QS. al-Māidah/5: 87.

${ }^{18}$ QS. al-Māidah/5: 3.

${ }^{19}$ QS. al-Baqarah/2: 275.

${ }^{20}$ QS. al-Baqarah/2: 178.

${ }^{21}$ QS. al-Baqarah/2: 200.

22 Edward William Lane, Arabic-English Lexicon (Cambridge: Cambridge University Press, 1972), Book 1, part 2, 477.

${ }^{23}$ QS. Hūd/11: 46.

${ }^{24}$ Muḥammad ibn Mukram ibn Manẓūr al-Afriqī al-Miṣrī, Lisān al-'Arab (Bayrūt: Dār al-Ihy al-Turts, 1996), Juz 11, 129.

25 Al-Azharī, Tahdzìb al-Lughah, juz 2, 258; Abū 'Abd al-Raḥmn al-Khalīl alFarāhị̣ī, Kitāb al-'Ayn, taḥīq: Mahụī al-Makhzkmī dan Ibrhīm al-Samrī (tt.: Dār wa Maktabat al-Hilāl, t.th), juz 3, 390; Ibn Manẓūr, Lisān al-'Arab, juz 11, 129; Abū al-Hasan 'Alī ibn Ism îl al-Naḥwī al-Lughawī al-Andalūsī, al-Mukhașis, tahqīiq: Khalīl Ibrhīm Jaffāl (Bayrūt: Dār al-Turāts al-'Arabī, 1417/1996), juz 1, 261.

26 I. Goldziher, Muhammedanische Studien, I, 219-28 (Halle 1889), terjemah Bahasa Inggris oleh: C. R. Barber and S. M. Stern, 201-8 (London 1967). Kutipan diambil dari: Franz Roshental, Knowledge Triumphant: the concept of knowledge in Medieval Islam (Leiden-Boston: Brill, 2007), 32.

${ }^{27}$ Franz Roshental, Knowledge Triumphant, 33.

${ }^{28}$ QS. al-Baqarah/ 2: 78.

${ }^{29}$ Muhammad ibn Mukram ibn Manẓūr al-Afriqī al-Miṣrī, Lisān al-Arab, Juz 12, 22. Mereka yang menyatakan bahwa al-ummī adalah ketidakmampuan untuk membaca menulis dengan tangan kanannya diambil dari riwayat Muqātil ibn Sulaymān. Lih. Abū Bakr Aḥmad ibn Husayn ibn 'Alī al-Bayhaqī, al-Sunan al-Kubrā (Hayderabad: Majlis Dā’irat al-Ma'̄rif al-Nizāmīyah al-Kinah, 1344 H.), Juz 7, 42.

${ }^{30}$ Abū 'Abdullāh ibn Muhạmmad ibn Abī Bakr al-Qurțukbī, al-Jāmi' li al-Aḥkm al-Qurn, (Riyāḍ: Dār 'Ālim al-Kutb, 1423/2003), Juz 7, 298-299.

${ }^{31}$ Abū 'Abdullāh ibn Muhammad ibn Abī Bakr al-Qurțukbī, al-Jāmi' li al-Aḥkm al-Qurn, Juz 7, 298.

${ }^{32}$ Muḥammad ibn Ismāīl Abk Abdullāh al-Bukhārī, al-Jāmi‘ al-Ṣahịih alMukhtașar, taḥīiq: Musțaf Dīb (Bayrūt: Dār Ibn Katsīr, 1407/1987), juz 2, 675; Abū al-Husayn Muslim ibn al-Hajjāj ibn Muslim al-Qushayrī al-Nīsābūrī, Șahịh Muslim (Riyāḍ: Dār Tayyibah, 1426/2006), Juz 1, 483; Abū Dāwud Sulaymān ibn al-Asy'ats al-Sijistānī, Sunan Abī Dāwud (Riyāḍ: Maktabah alMa ārif, 1424), 407; Aḥmad ibn Syu'ayb Abū 'Abd al-Raḥmn al-Nasī, Sunan al-Nasāī al-Kubrā (Bayrūt: Dār al-Kutub al-'Ilmīyah, 1411/1991), Juz 2, 74.

${ }^{33}$ Sebagai contoh penjelasan dalam Muslim, Sahīh Muslim, 481-483.

${ }^{4}$ Sejarah matematika selalu disandarkan pada Phytagoras. Ia mengenalkannya 
sekitar tahun 580-500 SM. Lih. Clifford A. Pickover, The Math Book: from Pythagoras to the 57th Dimension, 250 milestones in the History of Mathematics (New York: Sterling, 2009), 44.

${ }^{35}$ William P. Berlinghoff dan Pernando Q Geuvea, Math trough the Ages (Oxton: Oxton Hause Publishing dan The Mathematical Association of America, 2004), 194.

${ }^{36}$ Lih. Clifford A. Pickover, The Math Book, 84.

37 W. Montgomery Watt, Richard Bell: Pengantar Qur'ān, terj. Lilian D. Tedjasudana (Jakarta: INIS, 1998), 5.

38 Pada tahun 1892, C.C. Torrey telah mengaji secara khusus istilah-istilah perdagangan dalam al-Qur'ān, lih. Charles Cutler Torrey, The CommercialTheological Term in the Koran (Whitefish: Kessinger, 2009). Buku ini merupakan disertasi Doktor di Jerman, lih. W. Montgomery Watt, Richard Bell, 6.

39 Al-Zarqānī merujuk ke Tafsìr al-Alūsī Juz 11, 5. Lih. Muhammad 'Abd alAẓìm al-Zarqānī, Manāhil al-Irfān fì 'Ulūm al-Qur'ān, taḥqīq: Fawwāz Aḥmad Jamarlī (Bayrūt: Dār al-Kitb al-'Arabī, 1415/1995) juz 1, 297.

${ }^{40}$ Lih. Abū Bakr Ahmad ibn Husayn ibn 'Alī al-Bayhaqī, al-Sunan al-Kubrā (Hayderabad: Majlis Dāinah al-Maārif al-Nizāmīyah al-Kā’inah, 1344 H.), Juz 2, 146, 378; al-Nasāî̀, Sunān al-Kubrā (tk:tp, tt.), Juz 6, 18; 'Alī bin'Umar Abū al-Ḥasan al-Dāruqutnī al-Baghdāḍī, Sunān al-Dāruqutnī, Sayyid 'Abdullāh Hāsyim Yamānī al-Madānī (ed.) (Beirut: Dār al-Ma'rifah, 1386/1966), Juz 1, 354; Majd al-Dīn Abū al-Sa ādāt al-Mubārak ibn Muhammad al-Jazarī ibn alAtsīr, Jāmi' al-Ușkul fì Ahädth al-Rasūl, 'Abd al-Qādir al-Arnāūt (ed.) (Beirut: Maktabah Dār al-Bayān, 1970), Juz. 4, 401, 403,; Sunan al-Kubrā. No Hadits 9877.

${ }^{41}$ Abū Dāwūd Sulaymān ibn al-Asy'ats al-Sijistānī, Sunan Abī Dāwūd (Bandung: Dār al-Kitāb al-'Arabī, tth.), Juz 1, 373; Muhammad ibn Ismāeīl Abū 'Abdullāh al-Bukhārī al-Jū'fī, al-Jāmi' al-S'ah̄ih al-Mukhtașar (Yamāmah/Beirut: Dār Ibn Katsiir, 1407/1987), Juz 4, 1700.

42 'Abd al-Raḥmān ibn Kamāl Jalāl al-Dīn al-Suyūṭī, al-Durr al-Mantsūr (Beirut: Dār al-Fikr, 1993), Juz 3, 574.

${ }^{43}$ Abū al-Fidā' ibn 'Umar ibn Katsīr al-Dimasyqī (700-774 H.), Tafsīr al-Qur'ān al-'Az)īm, Sāmī ibn Muhammad Salmah (ed.) (Riyāụ: Dār Tayyibah lil-Naṣr wa-al-Tawzi', 1999/1420), Juz 6, 430, 467.

${ }^{44}$ QS. al-Baqarah/2:78. Al-Tabarī menakwilkan ummīyūn pada ayat ini merujuk pada riwayat dari Abū al-'̄Aliyah dan Mujāhid adalah segolongan orang Yahudi. Sedangkan riwayat Ibn Zayd menyebutkan bahwa ummīyūn adalah orang Yahudi yang tidak membaca kitab sucinya. Pada riwayat lain, dari Ibn 'Abbās, ia menafsirkan ayat ini dengan kaum yang tidak membenarkan (yusaddiquka): rasul-rasul yang diutus oleh Allah dan kitāb yang diturunkan Allah. Malah, mereka menuliskan sebuah kitāb dengan tangan mereka. Kemudian mereka berkata: "ini berasal dari sisi Allah." Muhammad ibn Jarīr ibn Yazīd ibn Katsīr ibn Ghālib al-Āmalī Abū Ja 'far al-Ṭabarī, Jāmi' al-Bayān fî Ta’wīl al-Qur'ān, taḥqīq: Aḥmad Muhammad Syākir (Riyāẹ: Muassasat al-Rislah, 1420/2000), 
juz 2, 257.

${ }^{45}$ QS. Alū 'Imrān/3: 20.

${ }^{46} \mathrm{QS}$. Alū 'Imrān/3: 75.

${ }^{47}$ QS. al-Jumu'ah/62: .2

${ }^{48}$ Ia menisbahkan kata al-ummī pada orang Arab yang tidak memiliki kitab suci, mereka tidak membaca, dan menuliskan satu kitab pun. Hal ini sesuai dengan penisbatan al-Nabi al-ummī kepada Nabi Muhammad, yaitu Nabi dari bangsa Arab. Kondisi Nabi yang ummī jauh dari apa yang diragukan orang bahwa dia memiliki kemampuan menulis. Kondisi yang mendekati pada kebenaran adalah dia memiliki musykilah sebagaimana umatnya. Muhammad ibn 'Umar ibn Husayn al-Rāzī al-Syāfī'ì, Mafātīh al-Ghayb min al-Qur'ān al-Karìm (N.p..: Dār Ihya' al-Turāts al-'Arabì, t.t.), Juz 30, 540.

${ }^{49}$ Merujuk pada al-Nūhas syang mengatakan bahwa al-ummī dikaitkan dengan Makkah. Hal ini disebabkan karena Makkah sebagai Umm al-Qur. Mungkin ia ingin mengatakan bahwa Nabi Muhammad adalah Nabi dari Makkah. Lih. Abū 'Abdullāh Muhammad ibn Aḥmad ibn Abī Bakr ibn Farḥ al-Khazrajī Syams alDīn al-Qurțubī, Al-Jāmi li Ạ̣kām al-Qur'an, Hisyām Samīr al-Bukhārī (ed.) (Riyāẹ: Dār 'Ālim al-Kutb, 2003/1423), Juz 7, 298.

${ }^{50}$ Ia lebih condong pada penjelasan bahwa al-Nabi al-ummī adalah Nabi yang diutus dari kota Makkah. Ia memberikan penguat dengan ayat wa-mā kāna rabbuka muhlik al-Qurā ḩattā yab'atsa fì ummīhā yaitu Makkah seorang rasul yang membacakan ayat-ayat Kami, yang diutus untuk semua wilayah (qurā). Zamakhsyārī dan Ibn Jawzī menafsirkan kata ummīha adalah ibukota suatu daerah atau wilayah. Abū al-Fidā' ibn 'Umar ibn Katsīr al-Qurasyī al-Dimasyqī (700-774 H.), Tafsìr al-Qur'ān al-'Azìm,Sāmī ibn Muhammad Salmah(ed.) Riyāẹ: Dār Tayyibah lil-Naṣr wa-al-Tawzī, 1999/1420), Juz 6, 248.

${ }^{51}$ Abū Ja far al-Ṭabarī, Jàmi' al-Bayān, juz 2, 257.

52 'Abd al-Raḥmn ibn Muhammad ibn Idrīs al-Rāzī ibn Abī Hātim, Tafsīr alQur'ān al-Ažim, tạ̣qīq: As'ad Muhammad al-Ṭayyib (Makkah: Maktabah Nizār Muṣtaf al-Bāz, 1417/1997), 1581.

${ }^{53}$ Abī Muḥammad al-Husayn ibn Mas‘ud al-Baghawī (w. 516), Ma ālim al-Tanzīl, ditahqīq: Muhammad Abdullāh al-Namr, 'Utsmān Jam'ah Himarīyah, dan Sulaymān Muslim al-Harsy (Riyāḍ: Dar Tayyibah, 1409), 288.

${ }^{54}$ Noldeke dan Schwally berpendapat ayat-ayat yang berkaitan dengan ummī adalah dalam periode Madinah. Dalam pandangan Noldeke, konsep ummī di dalam al-Qur'ān adalah konsep yang bertentangan dengan ahl al-kitab. Maksudnya, ummī merujuk kepada sebuah masyarakat tanpa wahyu. Schwally menganggap bahwa ummī berasal dari umma (bangsa, masyarakat) dan ini parallel dengan bahasa Yunani kuno (laikhos) dari (laos) yang artinya masyarakat; paralel juga dengan bahasa Syiriak-Aramaik 'almaya (saecularis). Schwally, tanpa menjelaskan lebih lanjut juga merujuk kata ummī kepada kosa kata Ibrani, 'arnha-ares. Theodor Noldeke and Friedrich Schwally, Geschichte des Qorans (Leipzig: Dieterichsche Verlag, 1909), 1, 14. Kutipan diambil dari Frederick Mathewson Denny, "The Meaning of "Ummah" in the Qur'ān," dalam History 
of Religions, Vol. 15, No. 1 (Aug., 1975), 40. The University of Chicago Press, http://www.jstor.org/stable/1061854. (diakses: 08/06/2011 04:25)

55 Horovitz menafsirkan kata "ummīyun" pada ayat di atas sebagai "ummot ha-olam " masyarakat yang tidak diberi kitab, berbeda dari para umat yang terdahulu yang menerima kitab. Menurut Horovitz, berbeda dari ayat yang telah disebutkan, makna ummiyun di dalam al-Baqarah/2:78, Bagi Horovitz, mereka ini adalah 'am-ha-ares, sekelompok Yahudi yang tidak mengetahui dan mengikuti Taurat, namun mengikuti hawa nafsu mereka. Horovitz berpendapat Muhammad bingung ketika mendengar kedua istilah; ummot ha’olam dan’amha-ares. Horovitz menyimpulkan Muhammad tidak mampu membedakan kedua istilah tersebut. Horovitz, Jewis Proper Name, 190; lih juga Frederick Mathewson Denny, "The Meaning...," 40

${ }^{56}$ Arent J. Wensinck, The Muslim Creed: Its Genesis and Historical Development (Cambridge: Cambridge Univerity Press, 1932), 7. Kutipan dari Frederick Mathewson Denny, "The Meaning...," 41

${ }^{57}$ W. Montgomery Watt, Bell's Introduction to the Qur'ann (Edinburgh: Edinburgh University Press, 1970), 34. Lih. Jane Dammen McAuliffe, Qur'änic Christians: An analysis of classical and modern exegesis (Cambridge: Cambridge University Press, 1991), 110.

${ }^{58}$ Abū Ja far Muhammad ibn Jarīr al-Ṭabarī (w. 310), Tafīir al-Tabarì: Jāmi alBayān 'an Tảwīl Āy al-Qur'ān, tahqīq: 'Abdullāh ibn 'Abd al-Muhsin al-Nazkī ( Kairo: Dār Hajr, 1422/2002),154.

${ }^{99}$ Syihāb al-Dīn Maḥmūd ibn 'Abdullāh al-Husaynī al-Alūsi (1217-1270), Rūh al-Ma'änì fì Tafsìr al-Qur'än al-'Azìm al-Sab' al-Matsānī, Juz 15, 295.

${ }^{60}$ Syihāb al-Dīn Mạ̣mūd Ibn 'Abdullāh al-Ḥusaynī al-Alksī, Rūh al-Ma'ānī fì Tafsìr al-Qur'ān al-'Azìm wa-al-Sab' al-Matsānī, Juz 6, 388.

${ }^{61}$ 'Alā al-Dīn 'Alī ibn Hịsyām al-Dīn (w. 975 H), Kanz al-'Ummāl fì Sunan alAqwāl wa-al-Afäl, tahqīq: Bakrī Haynī (Madīnah: Mu’assasah al-Risālah, 1401/1981), Juz 6, 211. Lih. Muhammad ibn Yazīd Abk 'Abdullāh al-Qazwīnī, Sunan Ibn Mājah, taḥqīq: Muḥammad Fud 'Abd al-Bāqī (Bayrkt: Dār al-Fikr, t.th), juz 2, 812 .

62 'Abd al-Raḥmn ibn Kaml Jall al-Ḍn al-Suykṭī, al-Durr al-Mantsūr (Beirut: Dār al-Fikr, 1993), Juz 3, 574.

${ }^{63}$ QS. al-Nisǟ/4: 113.

${ }^{64}$ QS. al-Mujādilah/58: 11.

${ }^{65}$ QS. Th/20: 114.

${ }^{66}$ Kisah masa lalu, contoh kisah Nabi Nūh, adalah bagian dari hal yang gaib yang Allah wahyukan pada nabi, QS. Hūd/ 11: 49. Pengetahuan tentang hari kiamat ada di sisi Allah dalam QS. al-A'rāf/7:187, al-Zukhrūf/ 43: 85, Fuș̣ilat/41: 47, al-Ahzb/33: 63, Luqmn/31: 34, al-Māidah/5:109. Pengetahuan tentang tauhid adalah dari Allah, penjelasan kepada kaum 'Ād (QS. al-Ahqf/46: 23. Pengetahuan tentang malaikat saat berbantah-bantahan adalah dari Allah dalam Șd/ 38:69. Sebelum Mūsā menjadi rasul, hịikmah dan kebijaksanaan diberi oleh Allah: al-Qașaș/28:14. Pengetahuan tentang umat terdahulu dari Allah 
(jawaban Mūsā atas pertanyaan Fir'awn), Th/20: 52. Pengetahuan tentang ruh ada di sisi Allah dalam al-Isrä'/17:85,

${ }^{67}$ Lih. Ellias Karim, “Scientits' Comments on the Qur'ān” dalam http://www. islamic-awareness.org /Qur'ān/ Science/scientists.html.

${ }^{68}$ Thomas J. O'Shaughnessy, Muhammad's thoughts on death: A thematic study of the Qur'annic data (Leiden: EJ. Brill, 1969), 5.

69 Ibn Hisyām, 1859-1860, kutipan dari Rudal Macuch, "On the Pre-History of the Credal Formula "there is no god but God" dalam Gerald R. Hawting (ed.), Development of Islamic Rituals, The formation of classical Islamic world: 26 (Cornwall: Ashgate, 2006 ), 11.

${ }^{70}$ C. Snouck Hugronje, "Meccan Feast" dalam Gerald R. Hawting (ed.), Development of Islamic Rituals, 247.

${ }^{71}$ M. Quraish Shihab, Mukjizat al-Qur'ān: ditinjau dari segi kebahasaan, isyarat ilmiah dan pemberitaan gaib (Bandung: Mizan, 1997), 210-212.

${ }^{72}$ Abū al-Faḍl Jall al-Ḍn 286Abd al-Raḥmn ibn Abī Bakr al-Suyūṭî, al-Itqān fì 'Ulūm al-Qur'ān, tahqīiq: Markaz al-Dirst al-Qurniyyah (Madīnah: Dār alFikr), 378.

${ }^{73}$ Lih. Ibn Abī Dāwud Abū Bakr 'Abdullāh ibn Sulaymān ibn al-Asy'ats al-Sijistānī al-Hanbalī, Kitāb al-Mas’hif, tahqīq dan naqd: Muhib al-Ḍn Abd al-Subh`n Wiz (Bayrkt: Dr al-Bașāir al-Islāmīyah, 2002), cet. 2, 153-168; Badr al-dīn Muhammad ibn 'Abdullāh al-Zarkasyī, Al-Burhān fī 'Ulūm al-Qur'ān, taḥqị: Muḥammad Abk al-Faḍl Ibrhīm (al-Qhirah: Dr al-Turāts, t.t.), Juz. 1, 233234.; Abū al-Fạ̣l Jalāl al-Dīn 'Abd al-Raḥmn ibn Abī Bakar al-Suyūṭī, al-Itqān fī 'Ulūm al-Qur'ān, taḥīq: Markj al-Dirst al-Qurniyyah (Maḍnah: Maktab alMalik Fahd li Tabah al-Muṣhaf al-Syarīf, t.t.), Juz 1, 377-391.

${ }^{74}$ Melalu analisis isnad cum matan, Harald Moztki menjelaskan bahwa apa yang diwacanakan oleh sarjana Barat mengenai awal dari sejarah pengumpulan adalah kurang tepat, ia menyimpulkan bahwa al-Qur'ān yang ada sekarang telah dibentuk sejak kuartal pertama Hijriah. Lih. Harald Motzki, "The Collection of the Qur'ān: A Reconsideration of Western Views in Light of Recent Methodological Developments" dalam Der Islam, Bd. 78, 1-34, Walter de Gruyter 2001, terutama halaman 25-26.

${ }^{75}$ Kata ini memang bukan bahasa Arab asli, melainkan kata serapan (loanword) dari Abysinia (Ethiopia). Pada bentuk Bahasa Arab yang benar mushaf diucapkan dengan mașhaf. Lih. J. Pedersen, Fajar Intelektualisme Islam: buku dan sejarah penyebaran informasi di Dunia Arab, terj. Alwiyah Abdurrahman (Bandung: Mizan, 1996), 134. Adapun orang yang diasumsikan sebagai orang pertama yang menyebutkan kumpulan șuhkkf sebagai mushaf adalah, Sālim ibn 'Ubayd ibn Ma'qil Mawlā Abū Hudzayfah. Lih. Claude Gilliot, "Reconsidering the Authorship of the Qur'ān” dalam Gabriels Said Reynolds, The Qur'ān in its Historical Context (London: Routledge, 2008), 94.

${ }^{76}$ Perdebatan mengenai küfì sebagai awal dari huruf Arab bisa dilihat di "The Qur'ānic Manuscript" dalam www.Islamic-awarness.com; lih. juga Nabia Abbot, The Rise of the North Arabic script and its Kur'anic development, with 
a full description of the Kur'an manuscripts in the Oriental Institute (Chocago: University of Chicago Press, 1939).

${ }^{77}$ Lihat MM. Azami, Sejarah Teks, 156.

${ }^{78}$ Al-Suyūțī, Al-Itqā̄n, 401.

${ }^{79}$ Al-Suyūṭī, Al-Itqān, 404.

${ }^{80}$ Al-Suyūṭị, Al-Itqān, 410.

${ }^{81}$ Lih. Abū Dāwud al-Sijistānī, Kitāb al-Mașhifi; al-Suyūțī, Al-Itqān, 417-421.

${ }^{82}$ Muhammad 'Abd al-'Az̄ìm al-Zarqnī, Manāhil al-287Irfn fì 287Ulkm al-Qurn, Fawwāz Ahmad Jamalī (ed.) (Bayrut: Dr al-Kitb al-Arabī, 1415/1995), 310316; Sya'bān Muḥammad Ism287ìl, Rasm al-Muséhaf wa Dabtuh: bayn altawqîf wa al-iștilhıt al-hadtsah (Makkah: Dār al-Salām, 1417/1997), 63-69; Mannā' al-Qaț̣n, Mabāḥīts fì 'Ulūm al-Qur'ān (Riyāḍ: Masyhkrt al-287Aṣr alHadits, 1493/1973), 146-150.

${ }^{83}$ Aḥmad ibn 287Alī ibn Hajar Abk al-Faḍl al-287Aṣqalnī al-Syāfí̀ Fath al-Bārī fì Syarh S’ạ̄īh al-Bukhārì (Bayrūt: Dār al-Ma rifah, 1379), juz 7, 504.

${ }^{84} \mathrm{Al}$-Khațīb al-Baghdḍ, Al-Jāmi li Akhlāq al-Rãwĩ wa Ādäb al-Sãmi', Juz 2/132, No 556. Hadits ini dianggap mawdk:

${ }^{85}$ Al-Suyūṭị, Al-Itqān, 2242.

${ }^{86}$ Al-Zarqānī, Manāhil al-287Irfn, 310.

${ }^{87}$ Sya'bān Muhammad Ism287īl, Rasm al-Musébhaf wa Dabtuh, 63.

${ }^{88} \mathrm{Al}$-Qaț̣n, Mabähīth fì 287Ulkm al-Qurn, 146.;

${ }^{89}$ Abū 'Amr 'Utsmān ibn Sa'ìd al-Dānī (w. 444), al-Muqni' fì ma'rifat marsūm ahl al-amṣr ma287a al-kitb al-nuqt, taḥqiq: Muḥammad Aḥmad Dahmān (Bayrūt: Dār al-Fikr, 1403/1983), 9-10.

${ }^{90}$ Al-Qaț̣n, Mabāhàts fì 'Ulüm al-Qur'än, 149.

${ }^{91}$ Al-Zarqānī, Manāhhil al-287Irfn, 312; Sya'bān Muhammad Ism287īl, Rasm al- Mushaf wa Dabtuh, 74.

${ }^{92}$ Al-Qațțn, Mabābìts fì 'Ulüm al-Qur'än, 148.

${ }^{93}$ Muḥammad Syar'ī Abū Zayd, "Jam' al-Qur'ān fì Marāḥil al-Trîkhīyah min al'Așr al-Nabawī ilā al-Aṣr al-Haḍt”, Tesis Universitas Kuwait, 1419, 147.

${ }^{94}$ Al-Zarqānī, Manāhil al-'Irfän, 312.

${ }^{95}$ Khalīd ibn 'Utsmān al-Sabt, Kitäb Manāhil al-'Irfān li al-Zarqānī (Madīnah: Dār Ibn 'Affān, 1413), Juz 1, 48.

${ }^{96}$ Ia menulis buku sekitar tahun 1385/1965.

${ }^{97}$ Mabāḥts disusun sekitar tahun 1393/1973.

${ }^{8}$ Sya bān Muhammad Ism287īl, Rasm al-Muṣhaf wa Dabtuh. Buku ini baru diterbitkan tahun 1997.

${ }^{99}$ Al-Suyūṭī, Al-Itqān, 2197.

${ }^{100}$ QS. al-Baqarah/2:124, 125, 258, 260.

${ }^{101}$ Sebagai contoh lih. QS. Âlu 'Imrān/3: 65, al-Tawbah/9: 114, Ibrāhīm/14: 35.

${ }^{102}$ Al-Suyūṭị, Al-Itqān, 2239. 